Vol. 6 (1997): 371-380.

\title{
The effects of a non-woven cover in combination with different soil mulches in strawberry cultivation
}

\author{
Abbas Aflatuni \\ Agricultural Research Centre of Finland, North Finland Research Unit, North Ostrobothnia Research Station, \\ FIN-92400 Ruukki, Finland, e-mail: abbas.aflatuni@mtt.fi
}

Riitta Kemppainen

Agricultural Research Centre of Finland, North Finland Research Unit, Kainuu Research Station, FIN-88600 Sotkamo, Finland

Alpo Heinonen

Agricultural Research Centre of Finland, North Finland Research Unit, Lapland Research Station, FIN-96900 Saarenkylä, Finland

Tiina Hakonen

Agricultural Research Centre of Finland, Data and Information Services, FIN-31600 Jokioinen, Finland

\begin{abstract}
The effects of a non-woven cover and three different soil mulches on the timing of harvest and on the yield of strawberry were examined in two field experiments in northern Finland during 1989-1993. The non-woven cover was used either in spring or in both autumn and in spring. Non-covered plants served as controls. Depending on the year, plants covered in spring alone gave a significantly earlier (4 to 9 days) marketable yield than did uncovered plants. The non-woven cover had no effect on marketable yield at Sotkamo but at Rovaniemi it increased the yield, especially in cold years. The use of cover decreased the amount of mouldy berries. At both experimental sites, a significantly higher yield was obtained from beds covered with soil mulches than from uncovered beds. White-on-black film delayed the yield by 2 to 4 days in comparison with black or Mypex film.
\end{abstract}

Key words: black film, early harvest, Mypex film, quality, timing, white-on-black film

\section{Introduction}

Non-woven covers are mostly used under cool conditions to advance strawberry crop growth early in the season (Laurinen and Säkö 1987, Davies 1992). A non-woven type of cover, such as Agryl or Lutrasil, provides a barrier against pest attack (Davies 1992). Begin (1988) found that plants ripened more quickly on plots covered with polypropylene-polyamide net (Agronet) in spring than on uncovered plots. According to Polling et al.(1991), overwinter covers improved early yields, but not the total 


\section{AGRICULTURAL AND FOOD SCIENCE IN FINLAND}

\section{Aflatuni, A. et al. A non-woven cover and soil mulches in strawberry cultivation}

marketable yield. Laurinen and Säkö (1987) reported that non-woven covers have, however, certain disadvantages, e.g. a slightly poorer crop quality and a large percentage of small berries (less than $1.5 \mathrm{~cm}$ in diameter), both of which reduce the quantity of the marketable yield. Pollard (1990) noted that Agronet row covers (extruded polypropylene-polyamide mesh) enhanced conditions in autumn and spring, thus possibly contributing to greater flower initiation and berry development. Clear polyethylene plastic over plants in spring creates a greenhouse effect, which advances the start of growth in early spring. This early growth results in earlier bud development and, subsequently, an earlier harvest, which, as shown by experience, is approximately 7 to 10 days earlier than that for organically mulched plants (Scheel 1982).

The most widely used soil mulch is black PE film. One disadvantage of black film is that it warms up the soil surface. The strawberry roots are then drawn closer to the soil surface than in uncovered soil, making the plants more susceptible to freeze injury (Leskinen 1977). The surface temperatures of clear, black and white plastic mulches were 17,19 and $15^{\circ} \mathrm{C}$ higher, respectively, than the surface temperature of bare soil. Both clear and black mulches advanced the earliness of the crop, increasing the potential danger from late spring frosts (Himelrick 1982). The temperature under mulch alone was highest for clear polyethylene and lowest for aluminiumcoated paper, with black polyethylene being intermediate between the two. Row covers over black polyethylene gave a higher soil temperature than did black polyethylene alone (Voth 1968). Generally, the superiority of plants on black polyethylene mulch was well sustained in the second year, the average yield being almost $90 \%$ higher than that from plants grown on bare soil (Laughlin 1968). Clear mulch increased fruit maturity by about 1 week, and black mulch by about 3 days, whereas white mulch had no effect on the time of maturity (Hopen and Oebker 1976). Pollard et al.(1987), Pollard and Cundari (1987), Pritts et al.(1989), Lieten (1991) and Himelrick et al.(1993) reported that in northern areas with short growing seasons and/or lowtemperature stress during winter or spring, spunbonded row covers of clear or black polyethylene advanced the strawberry harvest and improved strawberry yields in matted rows by increasing the growing degree units and by reducing heat loss from beneath the covers.

The main aim of this study was to answer the following questions:

1) Does the use of a non-woven cover or soil mulches or their combination advance harvest?

2) Is the yield of a crop protected by a non-woven cover in spring or in both autumn and spring greater than that of an uncovered crop?

3) Does the use of soil mulches increase the marketable yield?

4) Does black polyethylene mulch cause strawberry roots to grow nearer the soil surface than in bare soil?

\section{Material and methods}

Field studies were conducted in 1989-1993 at two stations in northern Finland, Sotkamo $\left(64^{\circ} 06^{\prime} \mathrm{N}, 28^{\circ} 20^{\prime} \mathrm{E}\right)$ and Rovaniemi $\left(66^{\circ} 35^{\prime} \mathrm{N}\right.$, $\left.26^{\circ} 01^{\prime} \mathrm{E}\right)$. The characteristics of the experimental soils are presented in Table 1. At Sotkamo fertilizer was applied to the rows before bed shaping at rates of $\mathrm{N} 0, \mathrm{P} 0, \mathrm{~K} 206 \mathrm{~kg} / \mathrm{ha}$, and at Rovaniemi at N 112, P 168 and $\mathrm{K} 184 \mathrm{~kg} / \mathrm{ha}$ in accordance with the general recommendations of the Soil Analysis Service of Finland.

The most commonly cultivated early strawberry in northern Finland is 'Zefyr', a variety of Danish origin. Plants of this variety were planted in June 1989 in rows of about $15 \mathrm{~cm}$ high and $5 \mathrm{~m}$ long. The rows were spaced $130 \mathrm{~cm}$ on cen-

Table 1. Characteristics of experimental soils.

\begin{tabular}{lrc}
\hline & Sotkamo & Rovaniemi \\
\hline $\mathrm{pH}$ & 6.7 & 6.8 \\
$\mathrm{P}, \mathrm{mg} / \mathrm{l}$ soil & 35.0 & 39.7 \\
$\mathrm{~K}, \mathrm{mg} / \mathrm{l} \mathrm{soil}$ & 214.0 & 225.0 \\
$\mathrm{Ca}, \mathrm{mg} / \mathrm{l}$ soil & 2025.0 & 2027.0 \\
$\mathrm{Mg}, \mathrm{mg} / \mathrm{l}$ soil & 231.0 & 438.0 \\
\hline
\end{tabular}




\section{AGRICULTURAL AND FOOD SCIENCE IN FINLAND}

Vol. 6 (1997): 371-380.

Table 2 . The periods that strawberry plants were protected with a non-woven cover in spring and autumn.

\begin{tabular}{llll}
\hline Station & 1991 & 1992 & 1993 \\
\hline Sotkamo & 5 May - 17 June & 13 May - 11 June & 7 May - 31 May \\
& $12 \mathrm{Aug}-16 \mathrm{Sept}$ & $11 \mathrm{Aug}-23 \mathrm{Sept}$ & $30 \mathrm{Aug}-1$ Oct \\
& & & \\
Rovaniemi & $14 \mathrm{May}-24 \mathrm{June}$ & $18 \mathrm{May}-9 \mathrm{June}$ & $15 \mathrm{May}-9 \mathrm{June}$ \\
& $5 \mathrm{Sept}-5 \mathrm{Nov}$ & $1 \mathrm{Sept}-1 \mathrm{Nov}$ & 31 Aug $-23 \mathrm{Sept}$ \\
\hline
\end{tabular}

tre, and were covered with three different soil mulches: woven cloth (Mypex film), black plastic film and white-on-black plastic film. The Mypex film is woven from polypropylene plastic strips and provide effective protection against UV-radiation. Water penetrates the film, which is $200 \mu$ thick, weighs $95 \mathrm{~g} / \mathrm{m}^{2}$ and is $100 \mathrm{~cm}$ wide. The black film, which is of UV-protected polyethylene is $60 \mu$ thick. The white-on-black film is coextruded polyethylene, $100 \mu$ thick. Noncovered plants served as controls. In combination with mulches, a non-woven cover (Lutrasil $17 \mathrm{~g} / \mathrm{m}^{2}$, white in colour with $92 \%$ light infiltration) was applied at two different times. The first application was in spring after the snow had melted and immediately after spring cleaning; this cover was left in place until flowering began. The second application was in autumn, and was used to extend the autumn season and protect the plant from early frosts. This cover was applied in August, after the harvest, and left in place until October; it was put back on again in spring. Table 2 shows the periods that the strawberry plants were covered with the non-woven cover in spring.

\section{Calculation and observation methods}

An early harvest was established by calculating how many days had elapsed from the first harvest day until the day when at least half of the marketable yield had been harvested. The total yield was classified into marketable yield, small berries, mouldy berries and others. Berries less than $1.8 \mathrm{~cm}$ in diameter were considered small. The quantity of small berries in the early harvest and the total yield were calculated. At the end of the experiment, the plants were removed carefully with their roots intact to find out whether roots under mulches grow at the soil surface or deeper down. The roots were washed and their length was measured. The region of root branches was examined and each root was assessed on a scale from 1 to 5 . If the roots were mostly branching on the upper side, they were rated 1 and if they were mostly branching on the downside, they were rated 5 .

\section{Weather conditions}

The plants received sufficient moisture from rainfall, and irrigation was therefore unnecessary. During the growing season, temperature and precipitation were monitored. Table 3 lists the monthly mean precipitation during growing seasons, Figure 1 shows the average temperatures from May to October in 1991-1993, and Figure 2 the sum of effective temperature (base ${ }^{\circ} \mathrm{C}$ ) at Sotkamo and Rovaniemi.

\section{Soil temperature measurement}

At Rovaniemi, the temperature of the soil was measured under cover and under mulches. The measurements were made at $7.00 \mathrm{am}$, at a depth of about $15 \mathrm{~cm}$. The differences in temperature between soils under cover and uncovered soils dur- 


\section{AGRICULTURAL AND FOOD SCIENCE IN FINLAND}

Aflatuni, A. et al. A non-woven cover and soil mulches in strawberry cultivation

Table 3. Monthly mean precipitation during growing seasons in 1991-1993 and long-term averages.

\begin{tabular}{llrrrr}
\hline & & \multicolumn{4}{c}{ Precipitation, mm } \\
\cline { 3 - 6 } Station & Month & 1991 & 1992 & 1993 & $1961-1990$ \\
\hline Sotkamo & May & 50.7 & 19.5 & 20.8 & 38.4 \\
& June & 149.0 & 26.9 & 56.7 & 55.5 \\
& July & 45.5 & 71.2 & 112.3 & 67.8 \\
& August & 60.7 & 139.5 & 77.0 & 88.5 \\
& September & 85.4 & 84.0 & 62.4 & 63.5 \\
Sum & May-September & 391.3 & 341.1 & 329.2 & 313.7 \\
Rovaniemi & May & 72.3 & 34.9 & 41.6 & 34.4 \\
& June & 94.0 & 109.6 & 59.5 & 54.4 \\
& July & 22.1 & 117.5 & 53.1 & 63.4 \\
& August & 60.3 & 147.4 & 31.5 & 68.6 \\
& September & 68.3 & 96.1 & 23.4 & 61.0 \\
Sum & May-September & 317.0 & 505.5 & 209.1 & 218.8 \\
\hline
\end{tabular}
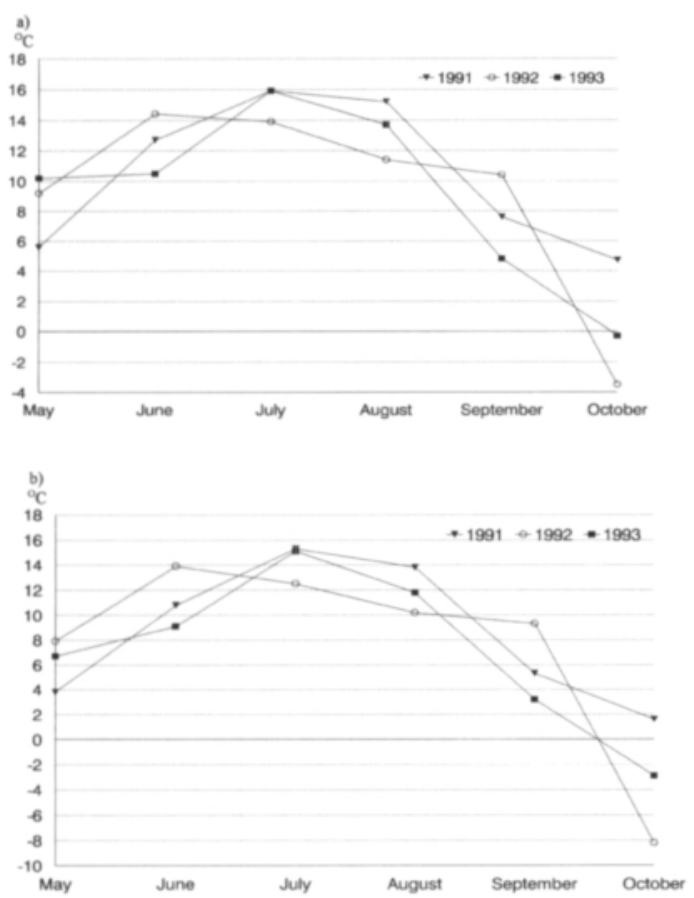

Fig. 1. Average of monthly temperature a) at Sotkamo and b) at Rovaniemi.


Fig. 2. Sum of effective temperature a) at Sotkamo and b) at Rovaniemi (base ${ }^{\circ} \mathrm{C}$ ). 
Vol. 6 (1997): 371-380.

Table 4. The 5-day average temperature $(0 \mathrm{C})$ under different soil mulches and crop covers at 7.00 am at Rovaniemi in 1991 and 1992.

\begin{tabular}{lccccc}
\hline Treatment & 16-20 May & 21-25 May & 26-30 May & 31 May - 4 June & 5-9 June \\
\hline Mypex \& Lutrasil & 6.50 & 8.95 & 9.51 & 11.88 & 11.61 \\
Black \& Lutrasil & 6.76 & 9.28 & 9.93 & 12.10 & 12.10 \\
White on black \& Lutrsil & 5.90 & 8.16 & 8.87 & 11.12 & 11.18 \\
Lutrasil & 6.58 & 8.50 & 9.34 & 11.40 & 11.30 \\
& & & & & 10.25 \\
Mypex & 5.30 & 7.39 & 7.80 & 10.42 & 10.60 \\
Black & 5.67 & 7.82 & 8.09 & 9.21 & 9.41 \\
White on black & 4.45 & 6.73 & 6.72 & 9.32 & 9.51 \\
No mulch or cover & 4.77 & 6.80 & 6.82 & &
\end{tabular}

ing May and June were similar. The highest temperatures were recorded with Mypex film and the non-woven cover or with black film and the non-woven cover (Table 4).

\section{Pesticide use}

At Sotkamo and Rovaniemi, supermetrin (Ripcord $0.05 \%$ ) was used against leaf beetle (Galerucella sagittariea) in 1991, 1992 and 1993. At Sotkamo tridimefon (Bayleton 0.03\%) was used against powdery mildew (Sphaerotheca alchemillae) in 1992 and 1993. At Rovaniemi there was no need to spray the plants against the above mentioned fungi and insects.

\section{Statistics}

The day at which $50 \%$ of the marketable yield was achieved, was assessed with 2 subsequential harvest days. The first day was when $50 \%$ of the marketable yield had not yet been achieved and the second day was when it had just been achieved. The days were usually 2 to 5 days apart. A linear estimation was used to establish the time that had passed before $50 \%$ of the marketable yield was achieved.

The statistical analysis was performed using analysis of variance (ANOVA) for a split plot design. The non-woven cover was the main plot, and the soil mulch was the subplot. The model included a time factor, the year of harvest, which was considered as a sub-subplot. The covariance structure for repeated measures was selected from unstructured, autoregressive and compound symmetry using the Akaike Information criterion (SAS 1992). The analysis was performed with the MIXED procedure of the SAS ${ }^{\circledast}$ software. The response variable was log-transformed, when necessary, to satisfy the statistical assumptions of the ANOVA. A P-value of less than 0.05 was considered statistically significant.

\section{Results}

\section{Timing of the harvest}

\section{Effects of non-woven cover}

The effect of the non-woven cover on the timing of harvest was significant at both experimental sites (Table 5).

\section{Effects of mulches}

The use of mulches had a significant effect on the timing of harvest at both experimental sites. At Sotkamo, in all 3 years, the effect of black film was statistically significant $(\mathrm{P}<0.01,0.05$, 


\section{AGRICULTURAL AND FOOD SCIENCE IN FINLAND}

\section{Aflatuni, A. et al. A non-woven cover and soil mulches in strawberry cultivation}

Table 5. Statistically significant effects of non-woven cover and mulch on timing of harvest, marketable yield, amount of mouldy berries, proportion of small berries and total yield at Sotkamo and Rovaniemi.

\begin{tabular}{|c|c|c|c|c|c|c|c|c|}
\hline Station & Source & A & B & $\mathrm{A} \times \mathrm{B}$ & C & $\mathrm{AxC}$ & $\mathrm{BxC}$ & $\mathrm{A} \times \mathrm{BxC}$ \\
\hline \multirow[t]{5}{*}{ Sotkamo } & Timing of harvest & $* * *$ & $* * *$ & NS & $* * *$ & $* * *$ & * & NS \\
\hline & Marketable yield & NS & $* *$ & NS & $* * *$ & NS & * & NS \\
\hline & $\begin{array}{l}\text { Amount of mouldy berries } \\
\text { in the early harvest }\end{array}$ & NS & NS & $*$ & $* * *$ & NS & NS & NS \\
\hline & Proportion of small berries & NS & NS & NS & *** & $* *$ & NS & NS \\
\hline & Total Yield & NS & $* *$ & NS & $* * *$ & NS & NS & NS \\
\hline \multirow[t]{5}{*}{ Rovaniemi } & Timing of harvest & $* *$ & $* * *$ & NS & $* * *$ & $* *$ & $* *$ & NS \\
\hline & Marketable yield & NS & $* * *$ & NS & $* * *$ & $* * *$ & NS & NS \\
\hline & $\begin{array}{l}\text { Amount of mouldy berries } \\
\text { in the early harvest }\end{array}$ & NS & NS & NS & $* * *$ & NS & NS & NS \\
\hline & Proportion of small berries & NS & NS & NS & $* * *$ & * & NS & NS \\
\hline & Total Yield & NS & $* * *$ & NS & $* * *$ & $* * *$ & NS & NS \\
\hline
\end{tabular}

$\mathrm{A}=$ effect of non-woven cover, $\mathrm{B}=$ effect of soil mulch, $\mathrm{A} \times \mathrm{B}=$ interaction between non-woven cover and soil mulch, $\mathrm{C}=$ effect of year, $\mathrm{A} \times \mathrm{C}=$ Interaction between non-woven cover and year, $\mathrm{B} \times \mathrm{C}=$ interaction between soil mulch and year and $\mathrm{A} \times \mathrm{B} \times \mathrm{C}=$ interaction between non-woven cover,soil mulch and year

${ }^{*}=\mathrm{P}<0.05,{ }^{* *}=\mathrm{P}<0.01,{ }^{* * *}=\mathrm{P}<0.001, \mathrm{NS}=$ no signifigant

0.05 in 1991, 1992 and 1993, respectively) in comparison with mulched plots. Black film advanced harvest by 1 to 2 days (Table 6), whereas white-on-black film delayed it, depending on the year, by about 1 to 2 days in comparison with no use of mulch, but the difference was statistically significant only in $1991(\mathrm{P}<0.001)$. At Rovaniemi, white-on-black film delayed the harvest be 3 days, on average, in comparison to no use of film (Table 6). However, this delay was not statistically significant in 1993.

\section{Interactions}

There was a significant interaction between the non-woven cover and the harvest years at both experimental sites (Table 5). Depending on the year, an early market yield was obtained from

Table 6. Effect of soil mulches on timing of strawberry harvest at Sotkamo and Rovaniemi.

\begin{tabular}{|c|c|c|c|c|}
\hline \multirow[t]{2}{*}{ Station } & \multirow[t]{2}{*}{ Soil mulch } & \multicolumn{3}{|c|}{ Days when $50 \%$ of marketable yield harvested } \\
\hline & & 1991 & 1992 & 1993 \\
\hline \multirow[t]{4}{*}{ Sotkamo } & Mypex & 13 & 15 & 15 \\
\hline & Black & 11 & 14 & 14 \\
\hline & White on black & 16 & 17 & 16 \\
\hline & No cover & 13 & 16 & 16 \\
\hline \multirow[t]{4}{*}{ Rovaniemi } & Mypex & 13 & 21 & 9 \\
\hline & Black & 11 & 20 & 8 \\
\hline & White on black & 16 & 26 & 10 \\
\hline & No cover & 14 & 22 & 9 \\
\hline
\end{tabular}


Vol. 6 (1997): 371-380.

Table 7. Effect of the non-woven crop cover on advancing of marketable yield harvest at Sotkamo and Rovaniemi.

\begin{tabular}{lllcr}
\hline Station & Covering season & \multicolumn{2}{c}{ Days when 50\% of marketable yield harvested } \\
\cline { 3 - 4 } & & 1991 & 1992 & 1993 \\
\hline \multirow{2}{*}{ Sotkamo } & Spring & 10 & 12 & 14 \\
& Autumn and spring & 11 & 15 & 14 \\
& No cover & 20 & 19 & 18 \\
\multirow{5}{*}{ Rovaniemi } & Spring & 12 & 21 & 9 \\
& Autumn and spring & 12 & 21 & 7 \\
& No cover & 21 & 27 & 14 \\
\hline
\end{tabular}

crops protected with the non-woven cover 4 to 9 days earlier than from crops not protected with such a cover (Table 7). There was also a significant interaction between the use of mulches and harvest years (Table 5).

\section{Marketable yield}

\section{Effects of non-woven cover}

Use of the non-woven cover had no effect on marketable yield.

\section{Effects of mulches}

In both experiments, a significantly higher yield was obtained from beds covered with soil mulches than from uncovered beds (Table 5). At Rovaniemi, although use of the white-on-black film



Fig. 3. Combined effect of non-woven crop cover and harvest year on marketable yield at Rovaniemi. increased the marketable yield, the difference was not statistically significant as compared with the yield from uncovered plots.

\section{Interactions}

At Rovaniemi, there was a significant interaction between the non-woven cover and the harvest year (Table 5). When the non-woven cover was used in autumn 1991 and spring 1992, the yield was significantly higher $(\mathrm{P}<0.01)$ than that from uncovered plots (Fig. 3). At Sotkamo, there was an interaction between soil mulches and the harvest year (Fig. 4). A significantly higher yield was obtained in 1991 with Mypex $(\mathrm{P}<0.001)$ and with black film cover in both 1991 and in 1992 $(\mathrm{P}<0.001$ and $\mathrm{P}<0.05)$ than with no bed cover. With the white-on black film, a significantly higher yield was obtained in all three harvest years $(1991$ and $1992 \mathrm{P}<0.001$ and $1993 \mathrm{P}<0.05$ ).

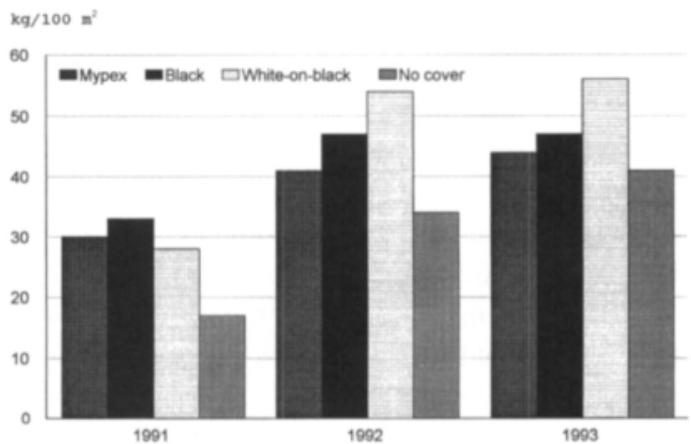

Fig. 4. The Combined effect of soil mulches and harvest year on marketable yield at Sotkamo. 


\section{AGRICULTURAL AND FOOD SCIENCE IN FINLAND}

Aflatuni, A. et al. A non-woven cover and soil mulches in strawberry cultivation

\section{Mouldy berries}

At Sotkamo, there was a significant interaction between the non-woven cover and soil mulches in the amount of mouldy berries (Table 5). When the non-woven cover was used in spring with black mulch, there were significantly fewer mouldy berries $\mathrm{P}<0.05$ ), than when no cover was used. At Rovaniemi, use of the non-woven cover in spring did not have a significant effect on the amount of mouldy berries, except in 1991 $(\mathrm{P}<0.05)$ when it decreased the amount of such berries.

\section{Small berries}

At Sotkamo, the effect of the non-woven cover on the proportion of small berries in the early harvest significantly depended on the harvest year. In 1991, use of the non-woven cover in spring, or in autumn and spring, $(\mathrm{P}<0.001$ and $\mathrm{P}<0.001)$ significantly increased the proportion of small berries in comparison with no use of the non-woven cover. At Rovaniemi, use of the non-woven cover in spring did not have a significant effect on the proportion of small berries in the early harvest in comparison with that of no use of the non-woven cover.

\section{Length and development of the strawberry root system}

Development of the strawberry root system was evaluated to see whether the roots were better developed near the surface of the soil or deeper down in the soil. The differences in the development and density of the roots were small. At Rovaniemi, the effect of the non-woven cover and mulches on the length of the strawberry root system did not differ significantly from that of a non-woven cover or mulch. At Sotkamo, only the use of Mypex film was statistically significant $(\mathrm{P}<0.01)$. In uncovered beds, the roots were 4 $\mathrm{cm}$ longer than in beds covered with Mypex film.

\section{Discussion}

In Norwegian trials, non-woven covers (Agryl p 17) advanced crop ripening by $5-6$ days (Meland 1986), and in Finnish trials by $3-5$ days (Laurinen and Säkö 1987). Polling et al. (1991) reported that, in general, plots covered either in spring or in both winter and spring gave higher early yields than did uncovered plots and, according to Karen et al. (1989), low temperatures in spring can damage flowers and delay anthesis and fruit ripening. Our 3-year field trial shows that use of a non-woven cover on plots in spring significantly advanced the harvest, which was 4 to 9 days earlier than in uncovered plots, depending on the year.

According to Pollard and Cundari (1987), use of a non-woven cover in autumn and in spring increases the marketable yield, and according to Wals and Loy (1985), row covers extend the season by retaining heat during periods of falling ambient temperature. Such covers are especially suitable for high-value field crops in climates where plants are exposed to low temperature stress or frost during autumn, winter or spring. In our present study, use of a non-woven cover in both autumn and spring at Rovaniemi, especially in a cold year like 1991, when the weather was exceptionally cold in September, and the frost came at the beginning of September already, led to an increase in the marketable yield. This increase suggests that the covers not only protected floral buds from early autumn frosts but that they may also extend the period of flower bud initiation. More studies should be carried out to establish whether or not non-woven covers really do have such a protective effect in autumn.

In northern latitudes non-woven covers did not have much effect on the size of berries. On the contrary, in warm years, they even reduced the marketable yield by increasing the percentage of small berries.

The present experiment showed that significantly higher marketable yields were obtained from beds covered with soil mulches than from unmulched beds. In warm years, the highest 


\section{AGRICULTURAL AND FOOD SCIENCE IN FINLAND}

Vol. 6 (1997): 371-380.

yields were obtained from beds covered with white-on-black film, indicating that such film may be the most suitable mulch for warmer areas. Lieten (1991) and Himelrick et al.(1996) also found that the white-on-black film gave the lowest soil temperatures, about $3^{\circ} \mathrm{C}$ below those with black polyethylene. This delayed cropping by a few days but gave a significantly higher yield.
Himelrik et al. reported that average soil temperatures from highest to lowest were found with black, black-on-white, clear, IRT-76, ALOR brown, red, silver and white-on-black film; the temperature of bare soil was the lowest of all.

As found elsewhere (Laurinen and Säkö 1987), the use of a row cover decreased the amount of mouldy berries.

\section{References}

Begin, S. 1988. Influence of floating row covers on the yield of June bearing strawberry. Proceedings of the Ontario Horticultural Conference. p. 31-43.

Davies, J. 1992. More from crop covers. Grower 118: 78.

Gast, K.L.B. \& Hall, N, \& Pollard, J.F. Overwintering strawberry plants under rowcovers: Effects on development of yield components. Acta Horticulturae 265: 215-216.

Himelrick, D.G. 1982. Effect of polyethylene mulch color on soil temperature and strawberry plant response. Advances in Strawberry Production 1: 15-16.

- , Dozier, W.A. Jr. \& Akrige, J.R. 1993. Effect of mulch type in annual hill strawberry plasticulture systems. Acta Horticulturae 348: 207-212.

- \& Woods, F.M 1996. Influence of mulch color on strawberry production in the Annual Hill Plasticulture System. Advances in Strawberry Research 15: 4248.

Hopen, H.J. \& Oebker, N.F. 1976. Vegetable crop responses to synthetic mulches, an annotated bibliography. Illinois University College of Agriculture Cooperative Extension Service Publication 42.

Laughlin, J.C. 1968. Strawberry trials with polythene. Tasmanian Journal of Agriculture 39, 3: 201-210.

Laurinen, E. \& Săkö, J. 1987. Cultivation of the strawberry in plastic house and under fiber-cloth cover. Annales Agriculturae Fenniae 26: 315-322.

Leskinen, A. 1977. Käytännőn marjanviljely. Summary: Practical berry cultivation. Helsinki. Puutarhaliiton opaskirjoja 24: 92-93.

Lieten, P. 1991. Multi-coloured crop production. Grower 116: 9-10.

Meland, M. 1986. Dekkemiddel ved tidlegproduksjon av jordbaer. Forskning og forsok i landbruket 37: 275280.

Pollard, J.E. 1990. The use of row covers to extend the strawberry growing season. In: The strawberry into the 21st century. Proceeding of the Third North American Strawberry Conference, Houston, Texas, 14-16 February. p. 153-157.

- \& Cundari, C.M. 1987. Improving strawberry fruit production with floating rowcovers. Proceedings of North American Strawberry Growers Association 6: 89-99.

-, Loy, J.B. \& Wells, O.S. 1987. A simple method for evaluating thermal transmission properties of plastic polymers for use as rowcovers. Proceedings of $\mathrm{Na}$ tional Agricultural Plastics Congress 20: 193-199.

Polling, E.B., Fuller, H.P \& Perry, K.B. 1991. Frost/Freeze Protection of strawberries grown on black plastic mulch. Horticultural Science 26: 15-17.

Pritts, M.P, Worden, K.A. \& Emaes, S. 1989. Rowcover material and time of application and removal affect ripening and yield of strawberries. Journal of the American Society for Horticultural Science 114: 531536.

SAS 1992. Technical Report P-229. SAS/STAT Software: Changes and Enhancements, Release 6.07. SAS Institue, NC,USA.

Scheel, C. 1982. The effect of clear polyetylene winter mulch on growth and yield of strawberries. North American Strawberry Growers Association 1: 29-30.

The role of crop covers 1993. Grower 119: 7-8.

Voth, V. 1968. Row covers over soil mulch compared to soil mulches in California strawberries. National Agricultural Plastic Conferance 8: 9-11.

Wells, O.S. \& Loy, J.B. 1985. Intensive vegetable production with row covers. HortScience 20: 822-826. 


\title{
AGRICULTURAL AND FOOD SCIENCE IN FINLAND
}

Aflatuni, A. et al. A non-woven cover and soil mulches in strawberry cultivation

\section{SELOSTUS}

\section{Katteiden käyttö mansikanviljelyssä}

\author{
Abbas Aflatuni, Riitta Kemppainen, Alpo Heinonen ja Tiina Hakonen \\ Maatalouden tutkimuskeskus
}

Maanpeite- ja kasvustokatteiden vaikutusta mansikan sadon ajoitukseen, määrään ja laatuun tutkittiin vuosina 1989-93 Pohjois-Suomessa. Harsoa käytettiin kokeessa kahdella tavalla: 1) harso levitettiin kasvuston päälle heti kevätpuhdistuksen jälkeen ja poistettiin kukinnan alkaessa, 2) edellisen lisäksi harso levitettiin uudelleen elokuussa sadonkorjuun jälkeen ja sen annettiin olla kasvuston päällä ilmojen kylmenemiseen saakka. Maanpeitteenä käytettiin Mypex-katekangasta, mustaa muovia tai valkoista muovia, jonka alapinta oli musta. Lisäksi verranteena kasvatettiin mansikkaa ilman harsoa ja katetta.

Harson käyttö aikaisti satoa 4-9 päivää. Kylminä keväinä harson käyttö lisäsi kauppakelpoista satoa hiukan, kun taas lämpiminä keväinä harso lisäsi pienten marjojen osuutta ja sen seurauksena vähensi kauppakelpoisen sadon määrää. Harson käyttö sekä syksyllä että keväällä ja erityisesti viileänä syksynä lisäsi kauppakelpoista satoa. Syynä saattaa olla se, että mansikan kukka-aiheiden muodostuminen voi jatkua syksyllä pidempään. Maanpeitekatteista vain musta muovi aikaisti satoa 1-2 päivää ilman maanpeitettä kasvatettuun mansikkaan verrattuna. Sen sijaan valkoinen muovi hidasti sadon kypsymistä 1-3 päivää. Ylensä maanpeitekatteiden käyttö lisäsi kauppakelpoista satoa. Kuumina kesinä paras kauppakelpoinen sato saatiin valkoisen muovikatteen avulla, joten sen käyttö on yksi vaihtoehto lämpimille alueille. 